\title{
Introducing Ross Chambers
}

\section{MEAGHAN MORRIS}

UNIVERSITY OF SYDNEY

It isn't an easy thing to introduce someone who has changed the course of your life. Given the honour of presenting Ross Chambers for his keynote address to the 2012 Cultural Studies Association of Australasia (CSAA) conference at the University of Sydney, I was so nervous and excited that I lifted his papers from the podium as I scurried to sit down. Beneath the dome of MacLaurin Hall there is vast space for embarrassment; people were calling out to me but I couldn't hear a thing. As Ross would mention during his lecture, MacLaurin can open up a 'memory hole' with a capacity to trouble the present materially for those who once read there (as he had when it held the Fisher Library) or faced exams there (as I did as an undergraduate). Flustered, I finally saw Ross saying 'you pinched my talk!' Then on my way back with the purloined papers I fell through forty years to a moment of stumbling in to his office, myself an ungainly student in an over-size T-shirt hugely proclaiming GAY LIB.

I have no idea why that particular moment of awkward visibility floated up from what Ross calls in this essay, 'the slow build up of silt we call life'. Certainly there were futures in that moment of 'minor trouble-making' from the early 1970s, futures that are past now and much more significantly his than mine. I may have been in his office to discuss writing a thesis on enunciation in eighteenth-century 
French women's novels, something I soon went on to do in a small way (and in bad French) in Paris. I would most certainly have been nervous. Professor Ross Chambers was overwhelming to Sydney students as the author of exotic critical works in the field of poetics: Gérard de Nerval et la poétique du voyage (1969), La comédie au chateau: contribution à la poétique du theatre (1971), and he must have been writing Spirite de Théophile Gautier: Une lecture (1974). In those days we did not commonly have professors who wrote books, let alone books in French, and it was hard for us to know what to make of this achievement. Later, Ross wrote in English from the United States a set of major works transforming literary theory into an urgent, difficult practice of cultural thought about the politics of 'poetics' in life. These included Facing It: AIDS Diaries and the Death of the Author (1998) and a magnificent book on the material effects of atrocity and witnessing in history, Untimely Interventions: AIDS Writing, Testimonial and the Rhetoric of Haunting (2004). Facing It was in part inspired by Unbecoming (1990), the diary of dying in Australia written by Eric Michaels, whose 'gay ethics of back-to-the-wall oppositionality' is the subject of a chapter in Untimely Interventions too. ${ }^{1}$ As some of you will know, Michaels was an American anthropologist whose brilliant studies of Warlpiri media practices had a shaping impact on cultural studies in Australia, in particular through his 1986 report for the Australian Institute of Aboriginal Studies (AIAS), The Aboriginal Invention of Television: Central Australia 1982-1986, and his tough, sassy essays that were mostly first published in our unrefereed little cultural magazines before being collected by the University of Minnesota Press in Bad Aboriginal Art: Tradition, Media and Technological Horizons (1993). Some of those magazines had their roots in 1970s social movements including Gay Liberation.

Not everyone doing cultural studies in Australia today does know these works and the political as well as historical links between them, and I think my time plunge after pilfering 'Toil and Trouble' had as much to do with the situated occasion of the conference brief as with the infantilising site of MacLaurin Hall. The 2012 theme was 'Materialities: Economies, Empiricism and Things' and, as the organisers have written elsewhere, one aim of the proceedings was to reflect on the recent resurgence of interest in materialism while remembering our discipline's 'long history of investigating material practices'2_ not least by inviting keynote speakers, including Ross, who had substantially contributed to writing that history. Also on 
the agenda, however (as Elspeth Probyn in particular insisted), was an effort to pull senior academics of my generation back into involvement with CSAA and to assume responsibility for thinking publicly about the past, present and future of the discipline. These two issues twisted together for me: the creative Australian past of cultural studies rarely figures in the refereed present of most routine stuff I read and that loss of inspiration is alienating. No doubt this reflects the material conditions of our funding-driven toil in the humanities generally now, but in the process of losing track of the local intellectual past we help to parochialise our perceptions of the present. A legend of literary studies in the United States and Europe, Ross Chambers is also an enabling figure for cultural studies in Australia, having taught, mentored, inspired or encouraged many of the academic seniors rounded up by Elspeth for the closing plenary of the conference. But the key point for me is that through to this very day-including his remarks that follow here on Julian Assange's autobiography and Fiona McGregor's novel Indelible Ink-no one has written more daring and consistently illuminating pages on the troubles of Australian culture than Ross Chambers, now Emeritus Professor of Romance Languages and Literatures at the University of Michigan, Ann Arbor.

Ross came to the University of Sydney as Professor of French when I was starting my Honours year, and it is hard to convey the quality of crisis that his arrival induced. In those days everyday life for students of French was organised by an endless quest for straight steel sewing pins. We also sweated over the language in new-fangled 'labs' and attended lectures in literary history that were often highly entertaining, but when it came to submitting our dictées and thèmes the only acceptable way to fasten the papers was with a pin in the top left hand corner. We were marked in Greek letters: alpha, beta, and on down to theta for 'fail'. The use of a staple or a paper clip incurred an instant theta. The reasons for this were lost even then in the oozy depths of time, but in this bizarre microclimate Ross Chambers was a revolutionary. He had no rules about pins that I recall, but his seminar made my head hurt with its demand for concentration. For the first time at university I could not immediately understand what was being said just by dropping No-Doz to stay awake. He taught us about structuralism, but he arrived as a practitioner of the related school of 'thematic criticism'. He made us read Tzvetan Todorov, Jean Starobinski and Jean-Pierre Richard in French, and he expected us to suspend the 
dreamy absorption we had always assumed was the virtuous way of approaching literary texts; he wanted us to read systematically for textual evidence, and to compile what might now be called 'data sets' before making interpretive claims. I was scandalised by this and I vividly remember asking in a surly tone: 'you seriously want us to go right through this novel noting every phrase relating to this theme?' When the shocking answer was 'yes!' I had my first lesson in the serious materialism of text as a process involving work rather than a litany of pious abstractions about language and social relations, and before computers it was very hard work indeed.

In time 1 learned to appreciate its rewards and a seminar that Ross gave with Anne Freadman not only decided me to try to study in Paris (this can change anyone's life) but left me with an abiding passion for the rhetorical and discursive 'data' that can be produced from texts using the work of Emile Benveniste on timing, situation, person and subjectivity ('enunciation') in language. ${ }^{3}$ This is a zone of theory I can rarely discuss in cultural studies' contexts but it is foundational for me and at some risk of hallucination I think I see traces of the form of Benveniste's thought in the clear, powerful distinction Ross makes in 'Toil and Trouble' between history and everyday life. In the mid-1970s, however, I was attracted to Benveniste's work (as interpreted by Ross) because it promised an evidence-based way to link the study of textual work to an account of contexts in historical and social life-the holy grail for materialist criticism at that time. In another floating memory I hear Ross saying, 'the énonciation must be the way' and in some feminist forum I used it to discuss Alix Kates Shulman's Memoirs of an Ex-Prom Queen (1972). I liked that, so for my Maîtrise thesis I took on Madame de Tencin's Mémoires du Comte de Comminge (1735).

However, the 'way' that Ross developed himself to understand writing in its socio-cultural materiality turned out to be much more challenging and substantial than I could ever have imagined. Let me situate this claim for a moment. Most cultural studies today is shot through with metaphysical idealism when it comes to mentioning 'text'; context and usage are all, and the idea of 'text' is merely a token for excluded or dépassé knowledge practices. Four decades ago, however, it was context that remained more or less tacit or taken for granted after an opening invocation; whether lived or, more commonly before feminism, established from secondary literature, the 'historical context' informed and framed materialist 
readings but was rarely a site of discovery in its own right. For example in $A$ Theory of Literary Production (1966) by Pierre Macherey, Althusser's student and collaborator, the Lukacsian concept of 'structuring absence' is brilliantly used to analyse how the novels of Jules Verne work in the 'context' of Macherey's own heroic effort to redeem the reflection model of literature's relationship to ideology and historical experience. Yet we learn little about the life of Verne's social times that could not have been generated directly from a good Marxist account of the crises of the later-nineteenth-century French bourgeoisie. ${ }^{4}$

One spectacular exception to this was Lucien Goldmann's stunning account of Jansenism in The Hidden God: A Study of Tragic Vision in the Pensees of Pascal and the Tragedies of Racine (1955), ${ }^{5}$ a monumental achievement of literary sociology that both troubled and inspired Raymond Williams. ${ }^{6}$ Ross made us read this too, precipitating on more than one occasion excited debates about seventeenth-century theology and the noblesse de robe (judicial nobility) on the then feminist, libertarian and gay refuge of Sydney's Lady Jayne Beach; and Goldmann's subtle handling of the explanatory tension between what we would later call 'structure' and 'agency' long helped to prevent me from engaging with the much more crude (as I still believe) versions of this problem I was beginning to encounter as 'Birmingham School' cultural studies.

Yet where Macherey's work seemed ultimately to refine the already-known about bourgeois ideology (context), Goldmann's attachment to the ideal of a homology (rather than a mirror) between particular signifying structures (texts) and a given social totality could reduce the analysis of the former to a closed allegorical exercise in generating 'fit'. It was within this somewhat airless impasse that Ross Chambers' Story and Situation: Narrative Seduction and the Power of Fiction (1984) opened a way that leads to cultural studies as well as to a materialist literary criticism. As though exemplifying Barthes' dictum that 'a little formalism turns one away from History, but ... a lot brings one back to it',7 Story and Situation showed how a rigorous reading of the enunciative situation of given acts of storytelling could draw out the latter's socio-cultural stakes by displacing the text/context opposition to ask the new question of 'point': what is the point of telling a story in a given context? How does the desire to make or to get a point organise relations between people telling stories and those who listen to them? Who has 
authority or wants to be in charge of the exchange? What happens to narrative point when the context of making it changes, as stories are re-told and re-contextualised? An obdurate reader of film and media texts myself, I have never stopped being guided by these questions from Story and Situation and I recall them whenever I feel stuck. But they are also crucial to the very process of asking questions and soliciting stories from others, as we do when we practise any kind of cultural ethnography.

At the same time, the reflection in Story and Situation on desire, narrative authority and the elusive power of fiction inaugurates what for me remains Ross Chambers' unique contribution to the core theoretical achievements of cultural studies: a conceptually stringent, concrete, multifaceted, plausible and above all unpredictably contextual way of understanding practices of opposition and their relationship to social change in the modern world. Projects for narrative authority and interpretive mastery are always being foiled or evaded in Ross Chambers' critical vision but in his work this emphasis on movement is not a romantic dogma but a practical question of politics: how? How does reading change us, and how does social change become possible? How do literature and culture participate in this? Arising from his studies in French modernism, this great theme begins to broaden in Room for Maneuver (1991), the first chapter of which opens with a section called 'Power in the Belly' on Paddy Roe's gularabulu: Stories from the West Kimberley as edited by Stephen Muecke. ${ }^{8}$ From there it continues gathering conceptual richness and historical scope through both of the books on AIDS writing and in his extraordinary book-length essai (the French term for a thought experiment is merited) on the digressive and the wayward in literature, Loiterature (1999). It is elaborated anew in his essay here on the materiality of time.

I love all these books and I have just begun to learn in earnest from the later ones; I feel almost grown up enough now to cope with their anger, their humour and their burning lucidity in facing the terrors that modern times have brought. When I feel discouraged by institutional life, however, it is to Room for Maneuver that I turn to recover hope. When I mentioned at the conference that this book about the 'leeway' in any system that allows opposition to take shape and change to occur had inspired my recent work with Mette Hjort on creativity and academic activism in building cultural studies, ${ }^{9}$ Ross scolded me for not citing his own muse for thinking about opposition, Michel de Certeau. But while I have read and cited de Certeau 
many times (perhaps too often), what I gain from Room for Maneuver that is not there for me intrinsically in de Certeau's famous distinction between strategy and tactics or his model of reading as poaching is the concrete sense of living and acting in a real space situated 'between the possibility of disturbance in the system and the system's power to recuperate that disturbance' (p. xi). The emphasis on 'between' here is mine, because this space of, as it were, a third potential-neither that of disturbance nor recuperation but rather that of 'maneuvering' between-is for me the place in which our academic everyday life is conducted and in which we have more leeway to act than we may daily feel that we do.

There is a great deal more to say about the contribution of Ross Chambers to the capacities of cultural studies but I would like to end as I began with a personal note. One of the most important lessons I learned as a young woman from Ross was an ethical stance; to keep a clear sense of what matters to me in intellectual life, to stick up for myself, and to fearlessly jump ship if those values were impossibly threatened. This was a hard lesson. Ross suddenly left the University of Sydney in 1975, after just three years as Professor, to take a position in French and Comparative Literature at Ann Arbor (where he was able to write those books). Thus he changed my life again, since after facing the prospect of writing a PhD without him I took a job writing film reviews for the Sydney Morning Herald instead-a great experience, as it happened. Before he left, though, he remarked that it was strange how an Australian university would hire someone because of things they did well (reading, writing and teaching) then bury them in administrative work so they could not do those things again. This was well before the neoliberal era in Australian higher education, though perhaps a harbinger of its coming, and it is a reminder that large historical shifts do tend to unfold along cultural grooves that already exist. More than any other literary thinker, Ross Chambers shows us how to see this actively shaped unfolding as one of the ways in which culture matters-and to find therein our own causes for creating value and hope in opposition.

Meaghan Morris is Professor of Gender and Cultural Studies at the University of Sydney, Distinguished Adjunct Professor at Lingnan University, Hong Kong, and 
Chair of the Inter-Asia Cultural Studies Society. Her most recent book is Creativity and Academic Activism: Instituting Cultural Studies (co-edited, 2012).

-WORKS BY ROSS CHAMBERS

Gérard de Nerval et la poétique du voyage, José Corti, Paris, 1969.

La comédie au chateau: contribution à la poétique du theatre, José Corti, Paris, 1971.

Spirite de Théophile Gautier: Une lecture, Lettres modernes, Paris, 1974.

Story and Situation: Narrative Seduction and the Power of Fiction, University of Minnesota Press, Minneapolis, 1984.

Mélancolie et opposition: les débuts du modernisme en France, José Corti, Paris, 1987.

Room for Maneuver: Reading (the) Oppositional (in) Narrative, University of Chicago Press, Chicago, 1991.

The Writing of Melancholy: Modes of Opposition in Early French Modernism, trans. Mary Seidman Trouille, University of Chicago Press, Chicago, 1993.

Facing It: AIDS Diaries and the Death of the Author, University of Michigan Press, Ann Arbor, 1998.

Loiterature, University of Nebraska Press, Lincoln, 1999.

Untimely Interventions: AIDS Writing, Testimonial, and the Rhetoric of Haunting, University of Michigan Press, Ann Arbor, 2004.

\footnotetext{
-NOTES

${ }^{1}$ Ross Chambers, Untimely Interventions: AIDS Writing, Testimonial, and the Rhetoric of Haunting, University of Michigan Press, Ann Arbor, 2004, p. 75.

2 Prudence Black, Fiona Allon, Catherine Driscoll, Elspeth Probyn, Kane Race and Guy Redden, Editorial Introduction to 'What Matters for Cultural Studies?', Inter-Asia Cultural Studies, vol. 14, no. 3, 2013, p. 427. The texts by Ien Ang, Tony Bennett, Stuart Cunningham, John Frow, Stephen Muecke, Tom O'Regan, Graeme Turner and myself collected in this special section are drawn from the closing plenary of the 2012 CSAA conference, referred to below.

3 Emile Benveniste, Problèmes de linguistique générale, Gallimard, Paris, 1966, pp. 225-85; Problems in General Linguistics, trans. Mary Elizabeth Meek, University of Miami Press, Coral Gables, 1971.
} 
4 Pierre Macherey, Pour une théorie de la production littéraire, Maspero, Paris, 1966; A Theory of Literary Production trans. Geoffrey Wall, Routledge and Kegan Paul, London and Boston, 1978.

${ }^{5}$ Lucien Goldmann, Le dieu caché ; étude sur la vision tragique dans les Pensées de Pascal et dans le théâtre de Racine, Gallimard, Paris, 1955; The Hidden God: a study of tragic vision in the Pensees of Pascal and the tragedies of Racine, trans. Philip Thody, Routledge, London, 1964.

6 Raymond Williams, 'Literature and Sociology: In Memory of Lucien Goldmann', New Left Review, no. 67, 1971, pp. 3-18.

7 Roland Barthes, Mythologies, Seuil, Paris, 1957; Mythologies, selected and trans. by Annette Lavers, Granada, London, 1973, p. 112.

8 Paddy Roe, gularabulu: Stories from the West Kimberley, ed. Stephen Muecke, Fremantle Arts Centre Press, Fremantle, 1983.

${ }^{9}$ Meaghan Morris and Mette Hjort (eds), Instituting Cultural Studies: Creativity and Academic Activism, Hong Kong University Press and Duke University Press, Hong Kong and Durham, 2012. 